The African Worker and the Universities' Mission to Central Africa in Zanzibar, 1864-1900

Michelle Liebst

Department of History, King's College London, UK

Address: Great Marston Barn, Risbury, Herefordshire, HR6 0NJ, UK

Email: michelle.liebst@gmail.com

Tel: 077887180532 


\title{
The African Worker and the Universities' Mission to Central Africa in Zanzibar, 1864-1900
}

\begin{abstract}
This research paper explores the connections between African workers and Christian missions in late nineteenth century Zanzibar, focusing on the Universities' Mission to Central Africa (UMCA), a High-Church Anglican missionary society. Procuring and managing labour was central to the everyday lives of Christian mission societies because missionaries demanded a range of skilled and unskilled workers - including builders, cooks, waterfetchers, porters and servants - in order to establish an ideal setting for the core aims: the conversion of souls and establishment of an African ministry. The missionaries constantly veered between submitting to local customs and conditions and imposing their own ideals of what they felt to be the proper management and division of labour. A good example of this was their employment of slaves, a practice that was not always illegal for British subjects and particularly widespread amongst explorers in need of porters. At the same time, the missionaries often had to abandon their belief that they must not exercise formal authority outside of the main nucleus of the clergy as they managed their labour forces and attempted to reform freed slaves into (ideally skilled) free wageworkers. These issues bear on how historians understand the tensions between conversion, cultural adaption, industrialisation and capitalism but it also says something of the role of missionaries and Christian Africans as cultural brokers between the mission economies and the local economies they interacted with. This article addresses the missionaries' employment of hire slaves, the attempts to establish Christian working communities and the use of household labour with regards to women and children.
\end{abstract}

Keywords: slavery, abolition, missions, UMCA, Christianity, Zanzibar, child labour

\section{Introduction}

It was the Christmas Day service of 1879 when the building work of Zanzibar's Slave Market Memorial Church was almost complete. ${ }^{1}$ Scaffold poles were adorned with palm branches and the floor was laid with grass mats. Benches and chairs were brought in for the use of the missionaries and the Europeans from the town; everyone else sat on the floor. The congregation, all dressed in their finest attire, was noted as an "effective and picturesque" symbol of the mission's progress as it included Arabs and ex-slaves, "Groups so similar, but assembled for how different a purpose!"² Six years earlier the site of the church had been "the last open slave market in the world", now it epitomised the presumed affinity between Christianity and anti-slavery as a "home of freedom" for "all colours and races." "With the 
initiative of Edward Steere, a UMCA Bishop (1873-1882), the edifice was said to be built by the freed slaves under the mission's care at the Mbweni shamba (farm), thus demonstrating the Universities' Mission to Central Africa (UMCA)'s commitment to teaching the work ethic and moral codes of labour inside and outside of school walls. The cathedral still stands today nearby a building with dark cellars popularly thought to be where slaves were kept and tour guides routinely inform tourists that the glorious juxtaposition to this dark past is that freed slaves built the cathedral as part of the missionaries' humanitarian efforts to provide employment and general care to the slaves who had been rescued by the British navy; thus marking the transition to wage labour to East Africa. ${ }^{4}$

However, in 1883 Steere was posthumously accused of employing slave labour to build this monument to Christianity and anti-slavery. Though hiring slaves was a common labour arrangement for Europeans and Indians in Zanzibar, most notably amongst the Imperial British East Africa Company (IBEAC) in the 1890s, which offended British audiences while slave owners saw it as hypocritical. ${ }^{5}$ This was quite a different matter from taking in runaway slaves or redeeming slaves, a practice that has been more widely researched. ${ }^{6}$ Aside from the controversy of Anglican missionaries employing slaves, this document highlights the fact that they relied heavily on African labour and that the question of who would perform what labour dominated the everyday lives of the mission. Indeed, something that has rarely been addressed in the historiography is that mission sources always featured concerns about labour in all forms, whether manual or clerical. Whether it was despair about the financial ruin of the mission funds from the expense of porters or being duped when paying for wages or commodities, the missionaries' relationships with African workers shaped their experiences. ${ }^{7}$ Moreover, far from simply taking on the role of aloof commentators on labour ethics of employers or slave owners, they grappled with the issue of how they should procure and 
manage African workers.

This paper therefore deals with the terms with which labour was extracted, how missionaries engaged with the labour market and how they tried to create their own Christian labour force. The African worker employed by the mission is usually written out of the historical narratives of missions or nascent capitalism and there is generally quite a minimal amount of research that considers any mission's role as small-scale economies and how they related to local economies. It is well known that missionaries sought the labour of Africans to spread the word of God amongst other Africans but historians have spent much less time on the missionaries' exploitation of labour in general; of the men, women and children who laboured as farmers, builders and servants. Given that the African ministry (which is the focus of much mission history research) was necessarily a male adult one, gender and childhood have consequently been neglected from the narrative. Observations of the contradictions between Christian ideas of freedom and Christian ideas of labour are probably the most common strain in historical research that connect missions and labour issues. Many historians have, for instance, reflected on the working conditions in the Church Missionary Society stations in Kenya that often surpassed the hardships of Swahili plantation slavery. ${ }^{8}$ However, thinking about the economy of mission should not simply demonstrate the contradictions of metropolitan ideals and missionary practice; many important and useful studies focus on how missionary education accompanied the material mediations of capitalism, including that of John McCracken, Johannes Fabian, Luise White, Jean and John Comaroff, Peter Pels and Keletso Atkins. ${ }^{9}$

So there is already a historiography on how - in the twentieth century in particular missionaries all over East, central and southern Africa brokered relations between African 
workers and colonial economies. This paper addresses the origins of this process by focusing on the actual employment of African workers. The first aspect of African labour attended to is the mission's recruitment of hire-slaves, which gives some texture to the understanding of the different terms on which slave labour was extracted. The second aspect that will be addressed is that of the labour of the potential and actual converts within the mission all of whom had previously been slaves. This includes the labour of students who boarded in the mission and the "adult" freed slaves on the settlement. However, it is first necessary to contextualise these issues by discussing the UMCA's ideologies in relation to cultural adaption, industrialisation and ideas of European "civilisation."

$* * *$

Tensions between worldly and religious matters demonstrate how the UMCA missionaries defined themselves against other missionaries and other Europeans in general. They were, for instance, at least as sceptical about the moral impact of European culture and "civilisation" on Africa - especially of European settler communities with their partiality to monetary excess and materialism - as they were of "heathenism". The UMCA were also opposed to the freed slave settlements set up by the CMS and the French Mission, arguing that it imposed a kind of "Christian communism" with unnatural and immoral Europeanised values. ${ }^{10}$ Objects of consumption and consumerism were, the missionaries thought, powerful agents of harmful aspects of European cultures. Some missionaries were much more tied to this principle than others because they feared that Africans were already in the process of "imitating." "It is wonderful how many men mistake Europeanization for real improvement," remarked Bishop Steere in a report to the Home Committee in 1873. He continued, 
I don't see what we should gain by introducing a travesty of European dress and language and manners, the natives are going in that direction only too fast for themselves and the first result is moral degradation. ${ }^{11}$

Missionaries who shared these views would therefore boast about their lack of belongings rather than their abundance. ${ }^{12}$ Yet at the same time, English luxuries such as afternoon tea and fine dining remained everyday practices for many missionaries and for the African convert, an invitation to such an event marked their status within the mission community. ${ }^{13}$

Still, for those missionaries dubious of European "civilisation" in Africa, immersion into African society was fundamental to the spread of Christianity by African agents. ${ }^{14}$ According to Steere, the difference between missions that focused on industry and those that focused on establishing an African ministry essentially reflected differences in doctrine:

The weakness of Roman missions with all their many excellencies lies in their artificiality and dependence upon foreign influences, the strength of Protestant mission with their innumerable defects lies in their putting a new power into native hands. ${ }^{15}$

So in many ways they sought to maintain customs of the country, albeit selectively. Indeed, missionaries tended to be highly critical of colonial labour policies and emphasised the dangers of applying European methods too quickly. For instance, they found from their own experience that there was no market for English or European methods of agriculture or mechanics except among the very few Europeans on the island and some of this was taken in by the Special Envoy, Bartle Frere. ${ }^{16}$ Yet despite their hopes to adopt African labour customs, the idea of allowing Christian adolescents to live and be apprenticed by local masons, as was 
the custom, was considered equally impossible because it was thought to be destructive to allow them to live with Muslims. ${ }^{17}$

Historians have already noted that the UMCA was unusual in that it disassociated itself with the project to combine missionary aims with economic development and "civilisation". 18 Instead, suspicious about urban life and about migration work, it sought for Africans a life of self-reliance in sedentary rural economies under the paternalistic civilising mission. ${ }^{19}$ These ideas were met with criticism and so a mission historian justified the UMCA as follows:

But what is a mission? The one great work is to make people Christians, because Christians believe in their religion as much as Mohammadans. To the world at large it is the civilising side of mission work that appeals, as being "something practical". In the eyes of those who believe in Christianity, religion is the great thing in life, and they believe that it is infinitely more important that men be religious than that they be carpenters or builders or clerks, or even houseboys and cooks to English residents. ${ }^{20}$

This contempt (or ignorance) of self-congratulary Victorian industry and urbanisation reflected their class and university backgrounds and nostalgia for a vision of pre-industrial England. ${ }^{21}$ Even if they did not necessarily support industrialisation, they did support industriousness. Like many missions, the UMCA at once sought to protect Africa and its traditions from the evils of modernity and civilisation and foster economic change. ${ }^{22}$ They advocated the spread of free wage labour, the cornerstone of the capitalist industries that offended them. ${ }^{23}$ However, the missionaries valued wage labour specifically because of its association with work ethics that promoted the dignity of labour, better "habits" and "improvement". Missionaries argued that, though the "Arab" slave owner may not be as cruel 
as the English slave owner in the Americas, the absence of wages hindered productivity and diligence. $^{24}$

For the missionaries, the biblical significance of labour and servitude was paramount. For example, missionaries preached about the Letter of Paul to the Thessalonians in which it was said, "if any would not work, neither should he eat. For we hear that there are some among you who walk disorderly, working not at all, but are busybodies." 25 Moreover, the attitudes to Christian labour being part and parcel of the cure for slavery were connected to the idea that worshipping God was like serving a master. At least some of the African converts seemed to have echoed this notion of being a Christian as a form of servitude towards God. As one freed slave boy ("a Zaramo Boy") described his journey from the slave trade to the mission he narrated that, "I was going to be sold away to Pemba, but Jesus carried me away to be His servant, and now I am trying to serve Him." ${ }^{26}$ In addition, UMCA's brand of Christianity was steeped in agricultural metaphors and allusions to church work as a way of serving God, as it was in many Christian missions. ${ }^{27}$ For instance, missionaries commonly called themselves "workers" or "labourers for the master's harvest". ${ }^{28}$

With respect to ending slavery, missionaries argued that the problem of slavery in Zanzibar ran so deep that failing to address it would mean a failure to address the spiritual matter as a whole. One of the missionaries' central self-perceived roles was therefore centred on guiding freed slaves to a new means of livelihood and nurturing a particular idea of freedom. The UMCA argued that the condition of slavery took away an individual's civil liberties and authority over their bodies and therefore also any incentive for self-improvement or morality. ${ }^{29}$ The destruction of slavery in Christendom was the template upon which Bishop 
Steere conceptualised the solution; slaves had to elevate themselves with Christianity so that they would become such good Christian slaves that they would finally shame their masters into manumitting them regardless of the legal status of slavery. ${ }^{30}$ This reading of St. Paul's perspective in the bible provided a point of comparison to the challenges that Moses faced with the slaves he famously freed and also demonstrated that it was up to the slave rather than the master to initiate moral improvement. Moreover, this very particular understanding of slavery helps to explain why it was ideologically acceptable for the UMCA missionaries to employ slaves to build a monument to anti-slavery. In contrast, the transition to free wage labour would, for British government officials, mostly come about through their "status of freedom," which was materialised by their freedom papers. ${ }^{31}$ They were less compromising or trusting with regards to the importance of self-reliance than the missionaries. John Kirk, the British consul for Zanzibar (1870-1886), believed the cure for slavery should be just as severe as its malady because "the freed slave will certainly not work unless compelled". ${ }^{32}$

Yet if the slave was to be bettered by their master, a Briton was not necessarily the best choice. Steere fiercely denied the assumption that the fact of having authority of a Briton would necessarily improve the African worker and he was extremely mistrustful of any European "possessed of absolute power" and "free from the immediate control of home opinion"; even the missionary should try and limit the extent of their authority. ${ }^{33}$ Still, the missionaries' central task was to lead the way for drastic changes in society and so it was necessary to claim some sense of authority that extended past clergy members and into the freed slave settlement, industrial training centres and amongst those employed outside of the mission community. In practice the missionaries did not simply leave African workers to take on an "improved" work ethic through Christian teaching alone. Despite the missionaries' criticism of the authoritarian approaches of the Catholic mission in Bagamoyo or the CMS 
mission in Rabai, not only did the missionaries find themselves extending their authority and discipline past the main nucleus of the clergy but they also had to manage the mission as a whole, which was in a very slow process of conversion. ${ }^{34}$ As for the skilled labourers or porters who were usually Muslim or Hindu, the missionaries invariably felt they similarly required direction and discipline, which of course should be no surprise given the importance of material development and service to the development of the mission itself. ${ }^{35}$

$$
* * *
$$

Having set out some of the UMCA's tenets the employment of slaves to build the Slave Market Church becomes somewhat clearer but in order to understand the situation fully we must first return to the debate and its specific context, secondly, consider the condition of the hire slave. The controversy was sparked off by an article in Mission Life by Robert Needham Cust, an East India Company civil servant and Orientalist, who in 1883 wrote to criticise the Society for the Propagation of the Gospel (SPG) in their Madagascar mission for furnishing their African missionaries' houses with upstairs rooms for their slaves and hiring slaves from local masters. ${ }^{36}$ Naturally, Cust's criticisms incited a reaction and so the SPG Reverend Francis Ambrose Gregory, who later became the Bishop of Mauritius (1904-1919), but was based with the SPG in Madagascar at the time, wrote a revealing counter-argument to Cust's article, claiming that Cust was out of touch with the compromises missionaries had to make, asking, "is not Mr Cust guilty of inhumanity in wishing to deprive the slave of any advantages he may get from living with a missionary?" ${ }^{37}$ Hence, Gregory was drawing on the quite common assumption that if there must be slaves, they would at least benefit from working for Christians. 
However, Chauncy Maples (UMCA missionary, 1876-1895 and Bishop of Likoma, 1895), who was based on the mainland in Masasi at the time, picked up on a different aspect of Cust's article. He noticed that Cust favourably contrasted the SPG mission with Bishop Steere's protest against slavery, which was exemplified by the construction of the Slave Market Church. ${ }^{38}$ Maples responded to Cust by declaring that " $[\mathrm{t}]$ he memorial church erected by Bishop Steere's skill on the site of the old slave market was built almost entirely by slave labour." ${ }^{39}$ Despite Maples' stated intention to defend "our brethren in Madagascar," he was in fact underlining the apparent hypocrisy of the missionary practice of hiring slaves and supporting Cust's view that missionaries should not countenance slavery and that "we should rather let them remain free heathens than become slave-Christians." ${ }^{\prime 4}$ Instead, his reply was probably intended to tarnish the memory of Steere's work in Zanzibar and confirm the superiority of his own labour ethics. ${ }^{41}$ Maples claimed that Steere's reasoning for hiring slaves was that "all the working-classes, masons, labourers, \&c., in Zanzibar, are slaves, and therefore if a church is to be built at all, it must be built by slaves." While Maples seemingly praised missionaries who trained their students to be good servants, he reserved his highest admiration for his own Masasi mission, where "very little domestic work" was to be done at all due to their idyllic lack of want for extravagancies such as imposing buildings, like the cathedral Steere had devoted much of his life's work. ${ }^{42}$

Horrified by Maples' outspokenness, the UMCA Home Committee managed to censor Maples' response to Cust so in the end the missionaries did not have to justify their use of hired slave labour to their fellow countrymen as a whole. Still, they did have to justify it to the Home Committee, who seem to have been previously oblivious to these practices until this debate emerged. Like the SPG in Madagascar, Steere paid slaves but some of their pay was relinquished to their owners. ${ }^{43}$ Although he had planned to have the freed slaves build 
the church, their labour was mainly confined to the Mbweni plantation, where they would harvest coral from the ground to transport to the church for building. Steere therefore sought the labour of skilled hire-slaves, including Hindu masons who were said to be the highest class of manual labourers in Zanzibar despite their slave-status. ${ }^{44}$ In one sense, this should not have been surprising. Building the cathedral required an enormous amount of diverse skills that the mission's freed slaves were unable to offer. Following Maples' accusation, many letters followed, which defended Steere against what was perceived to be an extremely harmful accusation. Most missionaries agreed that the mission had no choice but to hire slaves yet were deeply concerned about the effect this news would have on their financial support from home. ${ }^{45}$ For example, John Prediger Farler (who later became Slavery Commissioner in Pemba) insisted that, "there is a sense in which every Englishman in Zanzibar $[\ldots]$ may have employed slave labour" though this was done either unknowingly or as a result of a complete lack of other options. ${ }^{46}$ Even David Livingstone, the head-figure of so many anti-slavery missions, employed slave-porters. ${ }^{47}$ There was said to be a constant a pool of slave day-labourers available in particular spots in urban Zanzibar waiting for employers and Europeans did not necessarily - or at least not initially - realise that they were hire-slaves. $^{48}$

It was common for all kinds of foreigners to recruit slaves; Europeans, Indians and Americans hired them as domestic servants, soldiers and porters. ${ }^{49}$ According to Captain $\mathrm{H}$. A. Fraser, a British resident who hired slave labour on his sugar plantation, this was "almost the only labour obtainable in Zanzibar, and is universally employed by all foreign residents engaged in commerce; there being some thousands of British subjects besides myself who so employ it." ${ }^{50}$ Consequently, both local slave owners and anti-slavery lobbyists criticised them 
for their hypocrisy. Horace Waller, an anti-slavery activist and former UMCA missionary (1860-1863), was one of the most vehement critics of Britons who employed slaves:

\footnotetext{
"The truth is this: we don't eat the slaves, we work the life out of them instead. We are hand in glove with the slave-dealers themselves. [...] [T]he ferocious Arab half-caste who haunts central Africa is perfectly justified in stating to all who will listen to him that the English are only too glad to use slaves when they can." ${ }^{51}$
}

Despite all this controversy of hiring slaves, Farler argued that they were somewhat overreacting; they "could not understand such a peculiar society, a slave is a slave to them." 52 In fact, the use of slaves as servants or labourers was technically legal for British subjects outside of British dominions, as long as it did not entail, "a dealing or trading in purchase, sale, barter, or transfer, carrying away, removing, \&c., of such a slave." ${ }^{, 53}$ By 1888 it was illegal for British subjects to hire slaves through the slave master but it was still lawful to do so as long as they arranged a contract directly with the slave and did not go through their slave master or a contractor. ${ }^{54}$

This prevalence of hire slavery demonstrates what Stephen Rockel has long argued, that slavery and wage labour could coexist. ${ }^{55}$ As many historians have shown, the slave's condition could vary dramatically on the East Coast and as such Glassman argues that the only characteristics the various kinds of slaves had in common was that "their status as subordinated clients descended from kinless outsiders brought forcibly into coastal society." 56 In Zanzibar most of the urban slaves were wazalia, slaves who were born there and were therefore were recognised to be at the height of slave society, having cast away their associations with the washenzi ("barbarians") of the mainland. As a result, they gained their masters' trust and tended to be part of a category of hire slaves known as vibarua. These 
vibarua were day labourers who were paid wages, a share of which went to their masters. ${ }^{57}$ The share varied between different slave owners but in Zanzibar it seems it was commonly a fixed sum of two dollars per month, which would leave about six dollars for some of the best paid slave-workers, two of which would have been spent on their bare necessities. ${ }^{58}$ The work of the vibarua was extremely diverse, from manual labour to highly skilled work. Female and child vibarua tended to be engaged in more menial labour as cleaners, water carriers and sorters of gum-copal. ${ }^{59}$ Hired slaves were, to European observers' surprise, able to accumulate quite considerable capital and therefore tended to aim to buy their own slaves rather than purchase their own freedom as a way of attempting to accrue material and social benefits. ${ }^{60}$ In fact, Livingstone even recounted a case of a free person selling himself into slavery to collect the profit in order to buy slaves of his own. ${ }^{61}$

The UMCA missionaries were aware of these particular conditions of slaves and had to find their own space as employers within this economy. On the whole, the mission's approach to recruitment was not that of fanatical abolitionists but rather of employers attempting to understand and interact with particular labour customs. In the end, employing slave labour reflected the missionaries' attitude that outright rejection of local customs was futile. Still, employing slaves risked compromising support from home and the only way of solving this problem was to produce Christian workers from within the mission, which is precisely what they attempted to do.

$$
* * *
$$

This ambition to create a self-sustaining Christian labour force and community out of freed slaves highlights the paradox of the UMCA; namely, that despite their wish to disassociate 
themselves as a political entity, the only way that they could introduce a new way of life on their terms was to create some semblance of secular authority. In the nineteenth century as the British navy increased its success rate in capturing slaves and "liberating" them, concerns emerged about their "disposal" - to use the common contemporary term of British administrators. A significant number of mission enterprises strived to harness these displaced marginalised peoples, particularly children, to help establish mission communities and clergies. The missionaries were initially sceptical of the idea of a freed slave settlement, limiting themselves to educating freed slave children only. However, by 1875 the UMCA had begun taking in adult freed slaves and many of the children who had first come to the mission were now adults. ${ }^{62}$ They were therefore faced with the dilemma of how to find livelihoods for the members of their growing community. The missionaries quite quickly came to the consensus that this strategy was doomed due to the corrupting affects of slavery. ${ }^{63}$ They believed slavery caused these individuals to be incapable of "pure and honourable thought" and "utterly immoral, untruthful, and dishonest." 64 This echoes the prevalent notion amongst both British administrators and missionaries that slavery left a permanent mark on the individual.

As a result, missionaries increasingly rejected freed slaves from the British consulate in favour of "voluntary" local pupils whenever they could but voluntary students were rare as many parents feared for their reputation amongst "zealous Mohammedans" and they worried that the missionaries would "bewitch" their children. ${ }^{65}$ Though the missionaries still hoped that some freed slaves would establish the African ministry, they were increasingly pessimistic about their abilities and sought to provide an "industrial school" route for the majority of freed slave students in order to prepare them for life as free wageworkers. Missionaries feared that too much emphasis on academic life would render their student's 
bodies too weak for the manual labour that they would invariably have to face in adulthood, while simultaneously being unqualified teachers. ${ }^{66}$

The missionaries were also beginning to understand that for Africans there was a deep connection between the absence of family and being a slave. Amongst the Yao, the closest word they could find for freedom literally meant "of-the-family" and freedom from slavery could only truly be granted by a family member - not a missionary or Arab. ${ }^{67}$ It therefore followed that the mission had to establish conditions for freed slaves to start new families and benefit from the paternal and maternal guidance of the missionaries themselves. However, concerns grew about the artificiality of this situation because their authority did not sit well with their role as genuinely affectionate family members. ${ }^{68}$ Even for the students at the mission who had their own families nearby, entering the mission to be taught Christianity involved a similar form of distancing from their families. To take one example, a Kiungani student who went home for the holidays and, as a consequence of hearing that his parents almost persuaded him to desert Christianity, one of the missionaries sent him this message: "he that loveth father or mother more than Me is not worthy of Me". ${ }^{69}$ The significance of losing one's family - along with their community and property - also marked for the missionaries the inevitable failure of their cooperation with freed slaves.

In order for them to have a successful relationship with an African the missionaries insisted that the African should invest something of themselves but - according to the missionaries - they had nothing to lose. ${ }^{70}$ This is also why the belief that freed slaves were "always wanting something more" was so pervasive amongst the missionaries. ${ }^{71}$ They also complained that the freed slaves were obtained "indiscriminately"; they were not specially chosen. ${ }^{72}$ Maples believed that they were "the worst material we could possibly have had for 
our purpose" and by the 1890s the missionaries had appropriated a Swahili word meaning "proprietors" or "natives" (wenyeji) in a derogatory sense to describe the freed slave "element." 73 Farler argued that the freed slaves should be separated from the voluntary students to minimise moral contagion and establish something more like a reformatory; a place designed for young offenders. ${ }^{74}$ Far from indoctrinating a sense of the dignity of labour, much like the situation in the CMS station at Rabai where Bombay Africans perceived themselves to be superior to other Africans, the educated freed slaves felt the same way towards the "slaves" - as they called them - labouring on the mission plantation. ${ }^{75}$ Needless to say, the missionaries found this emerging hierarchy disconcerting. Moreover, the missiontaught industrial students struggled to compete with the labour market due to their bad reputation in the town. ${ }^{76}$

The mission plantation, known as the Mbweni shamba, began with even lower expectations than the freed slave schools. The shamba was a plot of land of about 12 acres populated by approximately 250 freed slaves at any one time. ${ }^{77}$ Though the mission was generally against the idea of taking in adults, supporting and employing and therefore disciplining them, the British government paid a fee towards each freed slave taken in by missionaries and it was an opportunity to establish a Christian labour force and finally relocate them to the mainland mission stations. ${ }^{78}$ They were given "small money payments" that increased over time as the labourers became more skilled until they reached the "ordinary rate of wages," hence emulating a system of apprenticeship. Wages would also be revoked in the event that the workers were guilty of drunkenness, immorality, theft or absence at church services. ${ }^{79}$ The freed slaves also had to pay a rent of one day's work per week or its equivalent value. ${ }^{80}$ 
The central idea was to impress upon them the value of work for wages but wages were not thought sufficient to maintain discipline. Supervision led by the msimamizi or "overseer" was considered essential to the productivity of the shamba workers who sometimes laboured in gangs. ${ }^{81}$ In fact, the same term - msimamizi - applied to the slave plantations on the east coast of Africa. ${ }^{82}$ This was the most senior position a male or female African could have within the mission aside from teaching and clergy posts. Each station had some and they were responsible for keeping discipline on mission farms, settlements and industrial schools. ${ }^{83}$ Given the limitations of the freed slaves' condition in the mission plantation, many fled or rebelled. ${ }^{84}$ Indeed, it has been noted that many missionaries in Africa accused freed slaves specifically of holding a grudge against their paternal authority and the UMCA missionaries were no different. ${ }^{85}$

One missionary claimed that if the shamba was taken over by an Arab the people would have "rather more freedom, a few less pice, and be a little less discontented than they at present are" ${ }^{86}$ This reflected the view of many Britons that it was best for Africans to be employed by "Arabs" who supposedly had no interest in improving their slaves' personal or professional morals. In the end the missionaries' concerns about making unnecessary work for the freed slaves, the fact that the labour costs usually equalled the worth of the crop and the failure of the industrial training to secure skilled jobs in the town meant that the UMCA subscribers' charitable donations were no longer invested into the scheme and the freed slaves were pushed harder than ever to find their own livelihood independent of the mission and by 1884 they decided to refuse any more adult freed slaves from the consulate. ${ }^{87}$

Given the expense of mission, the missionaries demanded a degree of self-sufficiency in that students and converts had to maintain the mission and therefore form part of the 
labour force that may be described as "household labour". Christian women were expected to perform some of this labour, which says something of the missionaries' expectations and the gendered division of labour. They were not trying to mould their female industrial students into skilled wageworkers but instead they sought to provide for the mission a source of voluntary labour and for the male Africans, good Christian wives. The "industrial" women and girls at Mbweni would do the washing for the missionary women and engage themselves in needlework, weaving, laundry (dhobi) and cultivating. ${ }^{88}$ These women who had learnt these kinds of skills were not so much encouraged to earn a wage but rather to become mothers and settle into a life of "domestic comfort and respectability." and nearby mainland areas needlework was strictly man's work, at the mission it was strictly women's work. ${ }^{90}$ This reflected the missionary urge to draw in at least some aspects of feminine ideals of domestication, in which needlework was a major portion of their labour and perhaps one of the few commercial skills that could still be regarded as feminine. ${ }^{91}$

In a purely practical sense, maintaining the mission at a low cost meant that missionaries had to train African children and adolescents how to manage the household. Work included cleaning, cooking, collecting water, serving during mealtimes, maintaining the grounds and washing clothes, including those of the missionaries. ${ }^{92}$ But this kind of labour was not only designed to save or make money but it was also used as a strategy of discipline, which shows that organised labour required discipline and discipline, too, required organis. All of these individuals contributed their labour in different ways and all of them were exposed to the missionaries' vision of a certain work ethic. For the freed slave children for whom manual labour was part of their curriculum of duty and discipline that contributed to the dynamics between missionary and child convert to reflect the relationship between master and servant. The children sometimes even acted as (sometimes, but not always, paid) 
personal servants (or "maids") to the missionaries, particularly on long journeys and because it was such a heightened sign of social class in England to have servants, the fact that missionaries had a fairly large labour force that would cater to their individual needs contributed to the luxury of personal service and indulgence that many condemned, though it was practiced all the same. ${ }^{93}$

In 1895 the only paid servant in the school was a Goan cook and so the maintenance of the school was left almost entirely to its students, with a greater share for the industrial students. The use of child and adolescent labour was common amongst Christian missions in Africa and the UMCA taught mission "boys" were considered good servants. ${ }^{94}$ From the students' perspective their role as servants meant that many felt exploited and rumour spread that the missionaries saw them only as a means of producing financial profit. ${ }^{95}$ The students' resistance included refusal to attend classes and complete chores and children also ran away. In order to ensure that this work was done, missionaries set out systems of superintendence amongst them, as the head boys' main responsibility was to ensure the work was done. This sense of self-regulation was particularly strong in the industrial school, apparently making the missionary a mere "figurehead" within this "self-governing body" ${ }^{96}$

\section{Conclusion}

Discussing the relationship between the African worker and the missionary in this way helps to demonstrate the roots of the emerging relationships of dependence that were closely connected to the rise of capitalism, the subordination of the labourer's position and the gendered nature of wage labour. While the missionaries believed that only Christianity could heal the wounds of slavery, the mission - and the larger nascent imperialist system - could not be separated from the system of slavery itself, firstly because they recruited slaves and 
therefore helped slave masters profit, and secondly because their attempts to create their own setting for "free" wage labour continued to place limitations on the worker. Moreover, the way in which household labour was incorporated into the curriculum suggests that from a young age students may have been doing very similar work to a slave in their master's house. Despite the mission's ideologies that valued a simple way of life over a materialistic or avaricious one, the missionaries nonetheless attempted to establish profitable, or at least selfsustaining economies and indulged in the luxury of service and this helps to show how an assumed position of superiority was articulated and resisted. If the central strategy of imperialism was to exploit the labour of the colonised, then the central strategy of missions was very similar, regardless of missionary opposition to liberal ideologies of triumphant capitalism, imperialism or European civilisation.

\section{Bibliography}

Anderson-Morshead, E. M. The History of the Universities' Mission to Central Africa 18591896. London, 1897.

Atkins, Keletso. The Moon is Dead! Give us our Money! The Cultural Origins of an African Work Ethic, Natal, South Africa, 1843-1900. Portsmouth, NH: Heinemann; London: Currey, 1993.

Bennett, Norman Robert. "The Church Missionary Society at Mombasa, 1873-1894." In Boston University Papers in African History, ed. Jeffrey Butler, 157-194. Boston: Boston University Press, 1964.

Bennett, Norman Robert. Arab Versus European: Diplomacy and War in Nineteenth-century East Central Africa. New York: Africana Publishing Co., 1986.

Bissell, William Cunningham. Urban Design, Chaos, and Colonial Power in Zanzibar. Bloomington IN: Indiana University Press, 2011.

Broomfield, Gerald W. Towards Freedom. Universities' Mission to Central Africa. Westminster, 1957.

Brown, Vincent. The Reaper's Garden: Death and Power in the World of Atlantic Slavery. Cambridge, Mass.; London: Harvard University Press, c2008.

Burton, Sir Richard Francis. The Lake Regions of Central Africa: a Picture of Exploration. London: Longman \& Co., 1860.

Campbell, Gwyn. An Economic History of Imperial Madagascar 1750-1895: The Rise and Fall of an Island Empire. Cambridge; New York: Cambridge University Press, 2005.

Cave, Basil S. "The End of Slavery in Zanzibar and British East Africa," Journal of the African Society 9, no. 33 (1909): 20-33.

Christie, James. Cholera Epidemics in East Africa. London: Macmillan \& Co., 1876. 
Colomb, Slave-Catching in the Indian Ocean: A Record of Naval Experiences, Captain. [S.1.]: Longmans, Green and Co, 1873.

Comaroff, Jean and John Comaroff. The Dialectics of Modernity on a South African Frontier, vol. 2. Of Revelation and Revolution. Chicago: Chicago University Press, 1997.

Cooper, Frederick. Plantation Slavery on the East Coast of Africa. New Haven; London: Yale University Press, 1977.

Cooper, Frederick. From Slaves to Squatters: Plantation Labour and Agriculture in Zanzibar and Coastal Kenya, 1890-1925 (New Haven: Yale UP, 1980).

Cooper, Frederick. "From Free Labor to Family Allowances: Labor and African Society in Colonial Discourse." American Ethnologist 16, no. 4 (November 1989): 745-765.

Coupland, R. The Exploitation of East Africa 1856-1890: The Slave Trade and the Scramble. Faber \& Faber Ltd, 1939.

Cust, Robert. "Madagascar: Slavery and Christianity." Mission Life, May 1883.

Deutsch, Jan-Georg. Emancipation Without Abolition in German East Africa, 1884-1914. Oxford: James Currey, 2006.

Fabian, Johannes. "Missions and the Colonization of African Languages: Developments in the Former Belgian Congo." Canadian Journal of African Studies 17, no. 2 (1983): 165-187.

Farler, John Prediger, The Work of Christ in Central Africa: A Letter to the Reverend H. $P$. Liddon. London, 1878.

Fair, Laura. Pastimes and Politics: Culture, Community, and Identity in Post-Abolition Urban Zanzibar, 1890-1945. Oxford, 2001.

Fraser, H. A., Bishop Tozer, J. Christie, and E. Steere, The East African Slave Trade, and the Measures Proposed for its Extinction, as Viewed by Residents in Zanzibar. London, 1871.

Fraser, H. A. A Letter to the Honourable Members of the Select Committee of the House of Commons Appointed to Inquire into the Question of the Slave Trade on the East Coast of Africa. London, 1872.

Frere, Henry Bartle Edward. Eastern Africa as a Field for Missionary labour. Four Letters to the Archbishop of Canterbury. London: 1874.

Freund, Bill. The African City: A History. Cambridge: Cambridge University Press, 2007.

Freund, Bill. The Making of Contemporary Africa: The Development of African Society Since 1800. Basingstoke: Macmillan, 1984.

Gaitskell, Deborah. "At Home with Hegemony? Coercion and Consent in African Girls Education for Domesticity in South Africa Before 1910.” In D. Engels and S. Marks eds. Contesting Colonial Hegemony: State and Society in Africa and India, 110-30. London: British Academic, 1994.

Githige, R. M. "The Issue of Slavery: Relations between the CMS and the State on the East African Coast Prior to 1895." Journal of Religion in Africa 16, fasc. 3 (1986): 209-225.

Glassman, Jonathon. Feasts and Riot: Revelry, Rebellion, and Popular Consciousness on the Swahili Coast, 1856-1888. Portsmouth; London, 1991.

Glassman, Jonathon. War of Words, War of Stones: Racial Thought and Violence in Colonial Zanzibar. Bloomington, Ind.: Indiana University Press; Chesham, c2011.

Glassman, Jonathon. "The Bondsman's New Clothes: The Contradictory Consciousness of Slave Resistance on the Swahili Coast." The Journal of African History 32 (1991): 277312.

Glassman, Jonathon. "Racial Violence, Universal History, and Echoes of Abolition in Twentieth-Century Zanzibar." In Abolitionism and Imperialism in Britain, Africa, and the Atlantic, ed. Derek Peterson. Ohio, 2010, 175-206 
Good, Charles M. The Steamer Parish: The Rise and Fall of Missionary Medicine on an African Frontier. Chicago: University of Chicago Press, 2004.

Goody, Jack. "Slavery in Time and Space." In Asian and African Systems of Slavery, ed. James L. Watson (Oxford: Blackwell, 1980), 16-42.

Gregory, F. A., "Madagascar." The Mission Field 2, Dec. 1878.

Gregory, F. A., "Slavery in Madagascar," Mission Life 14, July. 1883.

Heanley, R. M. A Memoir of Edward Steere: Third Missionary Bishop in Central Africa. London, 1888.

Hine, John Edward. Days Gone By: Being Some Account of Past Years, Chiefly in Central Africa. London: John Murray, 1924.

Iliffe, John. A Modern History of Tanganyika. Cambridge: Cambridge University Press, 1979.

Ingrams, William Harold. Zanzibar: Its History and Its People. Stacey International, London, 2007 [1931].

Johnson, William Percival. My African Reminiscences, 1875-1895. London: Universities' Mission to Central Africa, 1926.

Lambourn, R. G. P. "Zanzibar to Masasi in 1876: The Founding of the Masasi Mission," Tanganyika Notes and Records 31 (1951): 42-46, 42.

Landeg White, Magomero: Portrait of an African Village. Cambridge: Cambridge University Press, 1987.

Livingstone, David. Narrative of the Expedition to the Zambesi and its Tributaries: and of the Discovery of the Lakes Shirwa and Nyassa, 1858-1864. London, 1866.

Lyne, Robert Nunez. Zanzibar in Contemporary Times: A Short History of the Southern East in the Nineteenth Century. London: Hurst \& Blackett, 1905.

Madan, Arthur Cornwallis. Kiungani; or, Story and History from Central Africa. London, 1887.

Maples, Chauncy. "Sermon Preached on the Anniversary Day of the Universities Mission in 1895 at St. Andrew's Church." In Journals and Papers of Chauncy Maples, ed. Ellen Maples, 212-226. London, 1899.

Mangénya, Erasto A. M. Discipline and Tears. Dar es Salaam: Dar es Salaam University Press, 1984.

McMahon, Elisabeth. Slavery and Emancipation in Islamic East Africa: From Honor to Respectability. Cambridge: Cambridge University Press, 2013.

Matson, A. T. "Sewa Haji: A Note," Tanzania Notes and Records, no. 65 (1966).

Maxwell, David. "Freed Slaves, Missionaries, and Respectability: The Expansion of the Christian Frontier from Angola to Belgian Congo." Journal of African History, 54 (2013): 79-102.

McCracken, John. "Underdevelopment in Malawi: The Missionary Contribution," African Affairs 76, no. 303 (1977): 195-209.

Miers, Suzanne. Britain and the Ending of the Slave Trade. London: Longman, 1975.

Miers, Suzanne. "Slavery: A Question of Definition.” In Gwyn Campbell, ed. The Structure of Slavery in Indian Ocean Africa and Asia, 1-16. London; Portland, Or.: Frank Cass, 2004.

Miers, Suzanne, and Igor Kopytoff, “African 'Slavery' as an Institution of Marginality.” In Slavery in Africa: Historical and Anthropological Perspectives, ed. Suzanne Miers and Igor Kopytoff, 3-81. Madison; London: University of Wisconsin Press, 1977.

Morton, Fred. Children of Ham: Freed Slaves and Fugitive Slaves on the Kenya Coast, 1873 to 1907. Boulder, Colo.: Westview Press, 1990.

Newman, Henry Stanley. Banani: The Transition from Slavery to Freedom in Zanzibar and Pemba. London: Headley Bros., 1898. 
Nwulia, Moses D. E. Britain and Slavery in East Africa. Washington, D.C.: Three Continents Press, 1975.

Okia, Opolot. "The Windmill of Slavery: The British and Foreign Antislavery Society and Bonded Labor in East Africa." The Middle Ground Journal, no. 3 (2011): 1-35.

Patterson, Orlando. Slavery and Social Death: A Comparative Study. Cambridge, [Mass.]; London: Harvard University Press, 1982.

Pels, Peter. A Politics of Presence: Contracts Between Missionaries and Waluguru in Late Colonial Tanganyika. Harwood Academic Publishers, 1999.

Porter, Andrew. Religion Versus Empire? British Protestant Missionaries and Overseas Expansion, 1700-1914. Manchester: Manchester University Press, 2004.

Ranger, Terrence. "Godly Medicine: The Ambiguities of Medical Mission in Southeast Tanzania, 1900-1945." Social Science \& Medicine, Part B: Medical Anthropology 15, no. 3 (1981): 261-277.

Rockel, Stephen. "Slavery and Freedom in Nineteenth Century East Africa: The Case of Waungwana Caravan Porters." African Studies 68, no. 1 (2009): 87-109, 100.

Rockel, Stephen. "Wage Labor and the Culture of Porterage in Nineteenth Century Tanzania: The Central Caravan Routes." Comparative Studies of South Asia, Africa and the Middle East 15, no. 2 (1995) 14-24.

Rowley, Henry. Twenty Years in Central Africa. London, 1881.

Sheriff, Abdul. Slaves, Spices \& Ivory in Zanzibar: Integration of an East African Commercial Empire into the World Economy, 1770-1873. London: Currey, 1987.

Smith, C. S. "Slavery." In E. M. Anderson-Morshead, The History of the Universities' Mission 1859-1909, 392-453. London: Universities' Mission to Central Africa, 1909.

Steere, Edward. Some Account of the Town of Zanzibar. London, 1869.

Strayer, Robert W. The Making of Mission Communities in East Africa: Anglicans and Africans in Colonial Kenya, 1875-1935. London: Heinemann Educational, 1978.

"The Work at Likoma," Central Africa 20, no. 335, July 1902.

Waller, Horace. Heligoland for Zanzibar; or, One Island Full of Free Men to Two Full of Slaves. London, 1893.

White, Luise. Speaking with Vampires: Rumor and History in East and Central Africa. Berkeley, C.A.; London: University of California Press, 2000.

Wimbush, J. S. "My Impressions of Zanzibar Today as Compared with Two Years Ago." African Tidings. 1895.

\section{Notes}

1. UMCA archives, Bodleian Library of Commonwealth \& African Studies at Rhodes House, Oxford, [hereafter, UMArch], A1 (III) A, fo. 389, Edward Steere to W. H. Penney, 20 September 1881.

2. Heanley, A Memoir of Edward Steere, 249-51.

3. Ibid., 120-1; UMArch A1 (III) C, "First Quarterly Statement of Bishop Steere," 28 August 1875, 5.

4. Glassman, "Racial Violence, Universal History, and Echoes of Abolition in Twentieth-Century

Zanzibar," 176-180.

5. Many historians have already noted how widespread the British or German employment of slaves was yet missionaries' employment of slaves is rarely mentioned. Moreover, they do not consider how this may or may not have stood up to political and religious ideologies or how Africans may have perceived it. Nwulia, Britain and Slavery in East Africa, 173-4; Rockel, "Slavery and Freedom in Nineteenth Century East Africa," 100; Morton, Children of Ham, 138-9; Opolot Okia, "The Windmill of Slavery," The Middle Ground Journal, no. 3, (2011): 1-35.

6. See references to CMS in footnote 8 below. 
7. The missionaries constantly had difficulties conveying their wishes to workers and there was a sense of competitiveness between mission stations about who could train the best workers. Wilson's apparent ineptitude for handling financial issues or for getting the most out of their labour force is a good example of this: UMArch, A1 (VI) B, fo. 357 Farler to Bishop of Magila, 9 November 1881, 359. For concerns about the expense of porters see: A1 (V) A, fo. 6, "Pastoral Letter Addressed to the Clergy and Members of the UMCA by the Right Rev. the Bishop [Charles Alan Smythies]," Zanzibar, July $1885,7$.

8. For CMS see Glassman, Feasts and Riot, 107-8; Bennett, "The Church Missionary Society at Mombasa," 157-194; Bennett, Arab Versus European, 68-75; Nwulia, Britain and Slavery in East Africa, 153; Morton, Children of Ham, esp. chapter 3; Githige, "The Issue of Slavery." For a good summary of the difficult work environment led by the Holy Ghost Fathers in Bagamoyo see Iliffe, $A$ Modern History of Tanganyika, 84-5. Critical work on the UMCA's labour ethics are less widespread and perhaps best represented by White, Magomero, esp. 34-5, 37.

9. McCracken "Underdevelopment in Malawi," esp. 199; Fabian, "Missions and the Colonization of African Languages: Developments in the Former Belgian Congo," Canadian Journal of African Studies 17, no. 2 (1983): 165-187; Luise White, Speaking with Vampires; Jean Comaroff and John Comaroff, Of Revelation and Revolution, vol. 2; Pels, A Politics of Presence, esp. 271-5; and Atkins, The Moon is Dead!

10. UMArch A1 (III) A, fos. 89-90 Steere to Festing, 24 February 1873.

11. UMArch A1 (III) A, fo. 90 Steere to Festing, 1873.

12. Hine, Days Gone By, 86, 95-6, 98.

13. "The Work at Likoma," Central Africa 20, no. 335, July 1902, 117-119.

14. Porter, Religion Versus Empire? 225.

15. UMArch A1 (III) A, fo. 90 Steere to Festing, Zanzibar, 24 February 1873.

16. Foreign Office papers, Kew National Archives, London, [hereafter FO] 84/1391, Frere,

"Memorandum on Disposal of Liberated Slaves," 57; UMArch, A1 (III) A, fos. 5-8, Nugent West to St Andrew's College, 1874, 7; Frere, Eastern Africa as a Field for Missionary Labour, 1874, 23.

17. UMArch, A1 (IX), fo. 126-8 Farler to Penney, 1883.

18. Porter, Religion Versus Empire? 225, 227-9, 332-3; Ranger, "Godly Medicine," 261; Good, The Steamer Parish, 47.

19. Good, The Steamer Parish, 19.

20. Hine, Days Gone By, 117.

21. Ranger, "Godly Medicine," 261; Good, The Steamer Parish, 45-6.

22. Maxwell, "Freed Slaves, Missionaries, and Respectability," 80.

23. Cooper, Slaves to Squatters, 2; Freund, The Making of Contemporary Africa, 61.

24. Fraser et al. The East African Slave Trade, 5-6, 31-64, 34.

25. New Testament, 21 st Century King James Version, Thessalonians 3, 3.6-11.

26. Madan, Kiungani, 62.

27. UMArch A1 (V) A, fo. 2, Sermon by the Rev. Canon King, 30 November 1883 a letter from the Bishop.

28. UMArch A1 (III) A, fo. 6, Nugent West to St. Andrew's College 1874.

29. Fraser et al. The East African Slave Trade, 6.

30. Steere, Central African Mission, 14. This is remarkably similar to Hegel's interpretation of freedom through consciousness discussed in Patterson, Slavery and Social Death, 99.

31. Lyne, Zanzibar in Contemporary Times, 78.

32. UMArch TC E30, Kirk to Parliament, 22 September 1871.

33. Steere, Central African Mission, 15.

34. Iliffe, A Modern History of Tanganyika, 84-5.

35. Johnson, My African Reminiscences, 21.

36. Cust, "Madagascar," 193. Cust was reacting to a published extract of one of Gregory's letters, in particular to this comment: "The students are all married; each has a house, consisting of sitting-room, bed-room, and kitchen, with an upstairs room for his slaves." Gregory, "Madagascar," 581. 
37. Gregory, "Slavery in Madagascar," 302-306, 305. In Madagascar there was a similar system of hiring slaves and in the mid nineteenth century it was widely thought that slaves were in a better position than the free wage labourer who was forced into the imperial labour system. Campbell, $A n$ Economic History of Imperial Madagascar, 117-8.

38. Cust, "Madagascar," 193. It was also published in the anti-slavery society journal - should get that reference and see which published first.

39. UMArch A1 (IX), fo. 160, Maples, "Slavery and Christianity"; fo. 121 "To the Members of the Universities' Mission" 1882.

40. Cust, "Madagascar," 231.

41. UMArch A1 (IX), fo. 121, "To the Members of the Universities' Mission," 1882.

42. Ibid., 146-151, Maples, "Christianity and Slavery," 1883. There was also a sense that even Steere himself was embarrassed by the great cost of the cathedral. In fact, he insisted that it must be called the "Slave Market Church" rather than "Christ Church Cathedral," as it is more widely known, as a way of attempting to minimise any sense of extravagance. A1 (III) A, fo. 389, Steere to Penney, 20 September 1881.

43. UMArch A1 (VIII), fos. 154-5, Heanley to Penney, undated; A1 (IX), fo. 156 Farler to Penney, 17 November 1883; Johnson, My African Reminiscences, 33.

44. Christie, Epidemic in East Africa, 311.

45. Ibid., A1 (IX), fos. 154-5 Heanley to Penney, November 1883.

46. UMArch, A1 (IX), fos. 123-5, Hodgson to Penney, November 1882. For some useful insights into Farler's career as Slavery Commissioner see McMahon, Slavery and Emancipation in Islamic East Africa, 28-30, 68, 79, 89, 93.

47. "Livingstone's 1871 Field Diary: A Multispectral Critical Edition," 297c/103, 297c/110, 297c/123, 297c/130, 297b/135, 297b/143, especially 297b/145:

http://livingstone.library.ucla.edu/1871diary/; see also UMArch A1 (IX), fo. 156, Farler to Penney, $17^{\text {th }}$ November 1883.

48. Miers, Britain and the Ending of the Slave Trade, 150.

49. Sheriff, Slaves, Spices \& Ivory in Zanzibar, 149; Christie, Epidemic in East Africa, 331; Rockel, "Slavery and Freedom in Nineteenth Century East Africa," 100; Cooper, Plantation Slavery, 187-188. 50. Ibid., 1, 15. For a summary of the labour arrangements of entrepreneurs F. A. Fraser in Zanzibar and William Sunley in Johanna see Coupland, The Exploitation of East Africa 1856-1890, 174-9

51. Waller, Heligoland for Zanzibar, 7-9.

52. UMArch A1 (IX), fo. 156, Farler to Penney, 17 November 1883.

53. Fraser, A Letter to the Honourable Members of the Select Committee, 13.

54. Cave, "The End of Slavery in Zanzibar and British East Africa," 24; Nwulia, Britain and Slavery in East Africa, 174; Okia, "The Windmill of Slavery," 9, 11; Rockel, "Slavery and Freedom in Nineteenth Century East Africa: The Case of Waungwana Caravan Porters," African Studies 68, no. 1 (2009): 87-109, 100.

55. Rockel, "Wage Labor and the Culture of Porterage in Nineteenth Century Tanzania."

56. Glassman, "The Bondsman's New Clothes," 298.

57. Ibid., 291; Christie, Epidemic in East Africa, 312; Anderson-Morshead, The History of the Universities' Mission, 83.

58. Anderson-Morshead, The History of the Universities' Mission, 83; Steere, Some Account of the Town of Zanzibar, 11.

59. Glassman, “The Bondsman's New Clothes," 291-2; Cooper, Plantation Slavery, 184-9; Fair,

Pastimes and Politics, 117.

60. Fair, Pastimes and Politics, 118; Bissell, Urban Design, 42-3; Jan-Georg Deutsch, Emancipation without Abolition, 71.

61. Livingstone, Narrative of the Expedition to the Zambesi, 55.

62. FO 84/1357, Letter 47, Dr Kirk, 17 March 1875.

63. Johnson, My African Reminiscences, 34, 36.

64. UMArch TC C1, Farler to Penney, September 1884; TC C1, Capel to Bishop of London, 1884, $10-12$. 
65. UMArch A1 (III) A, fo. 428 Bishop Steere, August 1881.

66. UMArch A1 (V) A, fo. 6 Pastoral Letter Addressed to the Clergy and Members of the UMCA by the Right Rev. the Bp. [Charles Alan Smythies] printed in Zanzibar July 1885, 14.

67. Johnson, My African Reminiscences, 35-6.

68. UMArch, A1 (VIII), fos. 241-2, Dale to Travers, Kiungani 15 November 1895.

69. Doke, "The Linguistic Work of H. W. Woodward," 198. Woodward was a UMCA missionary between 1875 and 1932.

70. J. D., "Schoolboys in Zanzibar."

71. Frewer, "An African Overseer," 100; J. D., "Schoolboys in Zanzibar."

72. UMArch A1 (IV), fo. 1a West to Searle, Zanzibar, July 1873; A1 (III) B, fo. 461, Steere to

Festing, 5 March 1878; Johnson, My African Reminiscences, 34, 36.

73. Maples, "Sermon Preached on the Anniversary Day of the Universities Mission," 212-226, 215-6.

74. UMArch A1 (VI) B, fo. 441 Farler to Penney Kiungani Zanzibar August 1884.

75. It was also said that these educated freed slaves to procure a slave when they married. UMArch

A1 (IV) A, fo. 60, Capel to Steere, 30 January 1877.

76. UMArch A1 (IV) A, fo. 330, Hodgson to Penney, December 1880; 689 Capel to Randolph, 11

August 1884; Lyne, Zanzibar in Contemporary Times, 211. When the workmen left the mission they

also often left their assigned trades, meaning that their training was sometimes in vain: TC C1, Capel

to Bishop of London, 1884, 9.

77. Johnson, My African Reminiscences, 36, 51.

78. UMArch A1 (III) A, Steere, "The Free Village in Yao Land," (1876), 3-5; Rowley, Twenty Years in Central Africa, 253; Lambourn, "Zanzibar to Masasi in 1876," 42.

79. UMArch A1 (III) C, "First Quarterly Statement of Bishop Steere," 28 August 1875, 4.

80. UMArch A1 (III) B, fo. 483 Steere to Robins, July 1878; H. A. Forde, 'Zanzibar II', Mission Life, August 1882, 342.

81. UMArch A1 (IX) fos. 33-5, Johnson to Waller, 14 August 1894

82. Christie, "Slavery in Zanzibar as it is," 31; Goody, "Slavery in Time and Space," 36;

Cooper, Plantation Slavery, 161.

83. UMArch A1 (VI) B, fo. 357 Farler to Steere, Magila 9 November 1881, 360; Frewer, "An African

Overseer"; Tozer, "Miss Tozer to Miss Twining, Zanzibar, May 5, 1872," 250; some wasimamizi

were women, Bennett, "The Industrial Wing at Mbweni."

84. UMArch TC C1, Farler to Penney, 12 September 1884.

85. Maxwell, "Freed Slaves, Missionaries, and Respectability," 80.

86. UMArch A1 (IV) A, fo. 75, Capel to Steere, 2 March 1877.

87. UMArch A1 (VI) B, fo. 432 Farler to Penney, Algiers 29 April 1883; A1 (IV) A, fo. 330,

Hodgson to Penney, December 1880; fo. 689 Capel to Randolph, 11 August 1884; A1 (V) A, fo. 15,

Pastoral Letter by the Bishop of UMCA acts of the synods held at Lukoma, Newala, Magila and

Zanzibar between July 1887 and February 1888, V; Newala, II.; TC C1, Capel to John Jackson

[Bishop of London], 1884, 9; Anderson-Morshead, The History of the Universities' Mission, 282-3;

Lyne, Zanzibar in Contemporary Times, 211.

88. Anderson-Morshead, The History of the Universities' Mission, 281.

89. Ingrams, Zanzibar, 222.

90. Ingrams, Zanzibar, 222.

91. As Gaitskell discusses in, "At Home with Hegemony?"

92. Frere, Eastern Africa as a Field for Missionary Labour, 47.

93. UMArch A1 (V) A, fo. 6, "Pastoral letter addressed to the clergy and members of the UMCA by the Right Rev. the Bp." [Charles Alan Smythies] (Zanzibar, July 1885), 8; Rowley, Twenty Years in Central Africa, 178; Frere, Henry Bartle Edward, Eastern Africa as a Field for Missionary Labour:

Four Letters to the Archbishop of Canterbury (London, 1874), 39.

94. Newman, Banani, 154.

95. UMArch TC C1, Farler to Penney, 12 September 1884. Erasto Mangénya, a UMCA missioneducated Tanzanian civil servant, writes about missionary brutality and prejudice in Discipline and Tears, 29-30. 
96. Wimbush, "My Impressions of Zanzibar Today as Compared with Two Years Ago," 99. 